\title{
National Anthropometric Surveys in China
}

\author{
Taijie LIU ${ }^{a}$, Chuzhi CHAO ${ }^{a}$, Chaoyi ZHAO ${ }^{a}$; Rechard ZHAO ${ }^{b}$ \\ ${ }^{a}$ China National Institute of Standardization, Beijing, China; \\ ${ }^{b}$ Leatech Co. Ltd., Beijing, China
}

\begin{abstract}
The national body size surveys for young people as well as a middle scale survey update for adult people are introduced. More than 20,000 subjects aged 4 to 17 are measured from year 2005 to 2009 for the size survey for young people. Standards on the body size of Chinese young people are developed, in which values of different percentiles are given.
\end{abstract}

Another 3,000 subjects are measured in 4 different regions in China for the update survey for adult people. Previous survey on adult people from year 1986 to 1988 is also mentioned. 3D body scanning measuring is implemented in the latest two surveys. Sampling details as well as measurement items are presented.

A new national body size survey for adult people is now being initiated by CNIS in 2012 with support from China Ministry of Science and Technology. Biomechanics and human characteristic parameters are also considered to be covered.

Keywords: Anthropometry, body size, Survey, China

\section{Introduction}

Anthropometric data, which describes the characteristics of body dimension, is the basis of human-centered design, esp. for usability and safety. It is also widely used in the industrial design of clothing, furniture, sports ware, consumer product, machinery, personal protective equipments, vehicles, architectures etc. For this reason, more and more countries carried out national body size survey and set up anthropometric databases.

In China, the organization to undertake national body size survey is China National Institute of Standardization (CNIS). CNIS is a non-profit national research body, engaging in standardization research. The main responsibilities of CNIS are to conduct general, strategic, and comprehensive research of standardization, to research and develop comprehensive fundamental standards, as well as to provide scientific evidence for government policy-making. Most importantly, CNIS is committed to anthropometry and biomechanics standardization researches.

In this article, size surveys for a single gender or for a part of human body are not covered. Only comprehensive body size surveys initiated and carried out by CNIS are introduced.

\section{Nationwide anthropometric surveys}

\subsection{First national anthropometry survey for adult people}

The first national body size survey is carried out from 1986 to1987. Around 22000 subjects aged from 18 to 59 years among 16 cities and provinces are measured manually. 73 items (Table 1) is measured for each subject in this survey. Chinese adult people's body dimension standard, GB/T 10000-1988 is developed by CNIS thereafter. It's a pity that the data in the standard above is still widely used even today, although dramatic changes have taken place during the past 20 years. There is simply not enough data update for the moment. 
Table 1. Measurement items of data acquired in the 1980s survey.

\begin{tabular}{|l|l|c|}
\hline Body parts measured & Name of measurement items & Number of Items \\
\hline Head & $\begin{array}{l}\text { Head length, maximum head breadth, sagittal arc, } \\
\text { head circumference etc. }\end{array}$ & 5 \\
\hline Trunk & $\begin{array}{l}\text { Stature, eye height, shoulder tips distance, } \\
\text { waist circumference, chest circumference etc. }\end{array}$ & 56 \\
\hline Hand & Hand length, hand breadth, finger length etc. & 5 \\
\hline Foot & foot length, foot breadth etc & 3 \\
\hline Other & grip circumference, handgrip forces etc. & 4 \\
\hline
\end{tabular}

\subsection{First national body size survey for young people}

As body dimensions of Chinese people, especially the minors, have changed a lot with the development of economics and the improvement of living conditions. From 2006 to 2007, CNIS carried out a new national body size survey addressing the body sizes of young people. The target population of this survey is young Chinse people aged from 4 years old to 17 years old, which constitute $23.77 \%$ of the total population.

The random cluster sampling with stratum dividing is used in the survey. The body shape of the minors varies greatly due the vast region difference. In order to enhance the accuracy, stratified sampling according the regions is applied. According to the regional body shape differences, China is divided into six stratums as Northeast- North region, c region, The middle reaches of Chankiang River, The lower reaches of Chankiang River, Guangdong-Guangxi-Fujian region, Yunan-Guizhou-Sichuan region. The measuring places are assigned in 2 to 3 provinces or cities from each region above. Certain number of Kindergartens, primary schools, middle schools is selected. Subjects are grouped in age. Distribution of subjects is given in Table 2.

$3 \mathrm{D}$ body scanning as well as $2 \mathrm{D}$ scanning measurement is applied in this survey. Cubic markers with side length of $10 \mathrm{~mm}$ are applied before scanning. Before scanning with Human Solutions scanners, the following 20 landmark points will be stuck with markers for each subject: right ectocanthion, cervical, left acromion, right acromion, left shoulder tip, right shoulder tip, left angular inferior scapulae, right angular inferior scapulae, mesosternale, middle point of the nipples, left iliocristale, right iliocristale, right iliospinale anterius, lowest rib on right side, right radiale stylion, right radiale, right caput fibulae, right tibial, right trochanterion, inion. In combination of interactive measurement and auto-calculation, data-acquisition work is greatly reduced. Set of other measures are taken to guarantee accuracy.

As given in table 3, more than 150 body size items are measured in this survey. Items from ISO 7250 are also covered in table 3 . Fig. 1 to Fig. 5 shows dressing and postures of this survey.

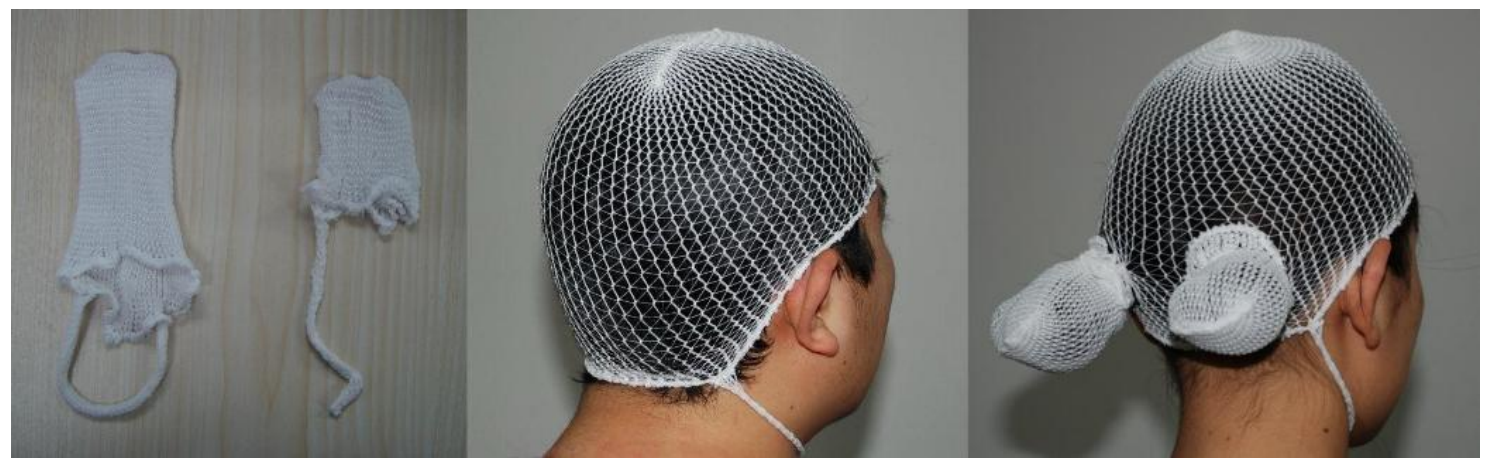

Fig.1 Cap for 3D scanning 


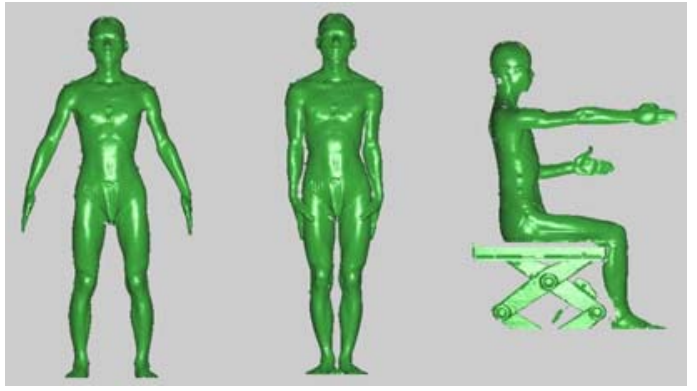

Fig.2. Postures for 3D body scanning.

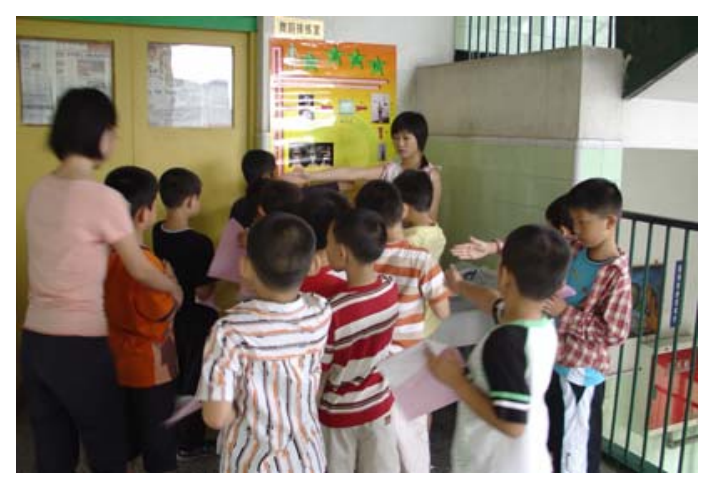

Fig.4. Illustration of scanning postures.

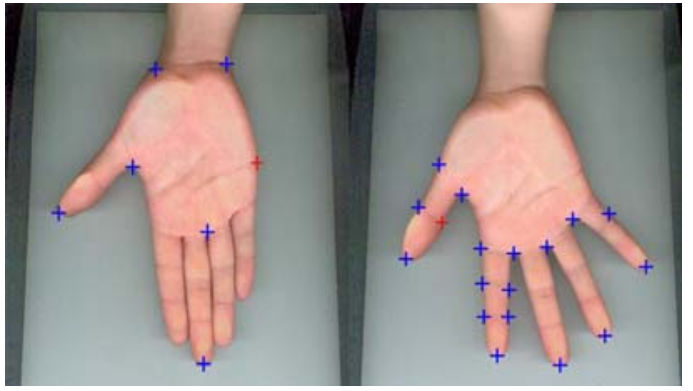

Fig.3. Postures for 2D hand scanning.

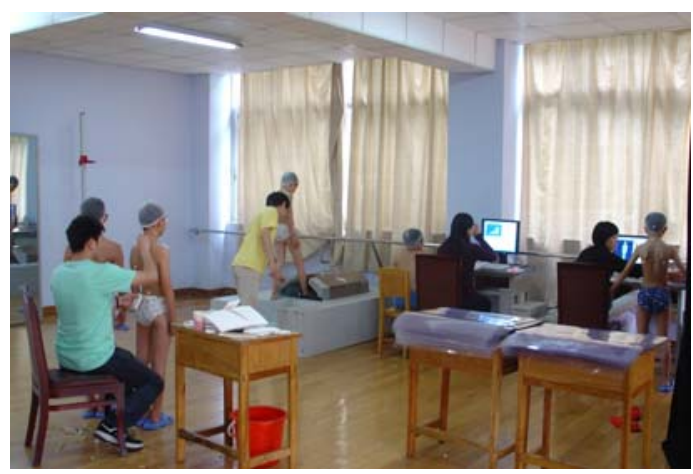

Fig. 5. On-site scanning.

For outcome of this survey, the following 5 China national standards were developed for the first time:

-- Human dimensions of Chinese minors

-- Apparel size designation of Chinese Minors

-- Head-face dimensions of Chinese Minors

-- Hand dimensions of Chinese Minors

-- Foot dimensions of Chinese Minors.

Table 2. Distribution of subjects in anthropometric survey for young people (2006 to 2007).

\begin{tabular}{|c|c|c|c|c|c|c|c|c|}
\hline \multirow[b]{2}{*}{ Age } & \multirow[b]{2}{*}{ Gender } & \multicolumn{7}{|c|}{ Region } \\
\hline & & $\begin{array}{c}\text { The middle } \\
\text { reaches of } \\
\text { Chankiang } \\
\text { River }\end{array}$ & $\begin{array}{c}\text { The middle } \\
\text { reaches of } \\
\text { Chankiang } \\
\text { River }\end{array}$ & $\begin{array}{l}\text { Northeast } \\
\text { - North } \\
\text { China } \\
\text { region }\end{array}$ & $\begin{array}{l}\text { Guangdong } \\
\text {-Guangxi } \\
\text {-Fujian } \\
\text { region }\end{array}$ & $\begin{array}{l}\text { Yuna } \\
\text {-Guizhou } \\
\text {-Sichuan } \\
\text { region }\end{array}$ & $\begin{array}{l}\text { Middle } \\
\text {-west } \\
\text { China } \\
\text { region }\end{array}$ & Total \\
\hline \multirow{3}{*}{$\begin{array}{c}\text { Age } \\
4 \text { to } 6 \\
\end{array}$} & Male & 209 & 177 & 193 & 92 & 212 & 201 & 1084 \\
\hline & Female & 217 & 210 & 188 & 90 & 208 & 201 & 1114 \\
\hline & Sub-Total & 426 & 387 & 381 & 182 & 420 & 402 & 2198 \\
\hline \multirow{3}{*}{$\begin{array}{c}\text { Age } \\
7 \text { to } 10\end{array}$} & Male & 405 & 337 & 406 & 222 & 423 & 360 & 2153 \\
\hline & Female & 387 & 390 & 422 & 214 & 426 & 348 & 2187 \\
\hline & Sub-Total & 792 & 727 & 828 & 436 & 849 & 708 & 4340 \\
\hline \multirow{3}{*}{$\begin{array}{c}\text { Age } \\
11 \text { to12 }\end{array}$} & Male & 366 & 342 & 367 & 209 & 421 & 341 & 2046 \\
\hline & Female & 345 & 341 & 354 & 192 & 391 & 355 & 1978 \\
\hline & Sub-Total & 711 & 683 & 721 & 401 & 812 & 696 & 4024 \\
\hline \multirow{3}{*}{$\begin{array}{c}\text { Age } \\
13 \text { to } 15\end{array}$} & Male & 593 & 473 & 494 & 281 & 544 & 493 & 2878 \\
\hline & Female & 547 & 462 & 509 & 269 & 517 & 461 & 2765 \\
\hline & Sub-Total & 1140 & 935 & 1003 & 550 & 1061 & 954 & 5643 \\
\hline \multirow{3}{*}{$\begin{array}{c}\text { Age } \\
16 \text { to } 17\end{array}$} & Male & 332 & 275 & 369 & 171 & 298 & 341 & 1786 \\
\hline & Female & 333 & 283 & 382 & 176 & 359 & 305 & 1838 \\
\hline & Sub-Total & 665 & 58 & 751 & 347 & 657 & 646 & 3624 \\
\hline
\end{tabular}




\subsection{Update anthropometric survey for adult people}

Update for body sizes of adult people is in great request as current data was acquired more 20 years ago. Due to support limitations, an update survey for about 3,000 adult people was made among 4 different regions in China in 2009. Distribution of subjects is given in Table 4. 3D body scanning technique is used in this survey again.

Table 3. Measurement items of data acquired via 3D body scanning.

\begin{tabular}{|l|l|c|}
\hline Body parts measured & Name of measurement items & Number of Items \\
\hline Head & $\begin{array}{l}\text { Head length, maximum head breadth, sagittal arc, } \\
\text { head circumference etc. }\end{array}$ & 14 \\
\hline Trunk & $\begin{array}{l}\text { Stature, eye height, shoulder tips distance, etc. } \\
\text { waist circumference, chest circumference et. }\end{array}$ & 22 \\
\hline Hand & Hand length, hand breadth, finger length etc. & 8 \\
\hline Foot & foot length, foot breadth etc & 2 \\
\hline other & Body height, middle fingertip height (over head) \\
\hline
\end{tabular}

Table 4. Distribution of subjects in an update survey for adult people in 2009.

\begin{tabular}{|l|l|l|l|}
\hline Site & Male & Female & Total \\
\hline ShaanXi Province & 492 & 468 & 960 \\
\hline Tianjin City & 425 & 444 & 869 \\
\hline Shanghai City & 450 & 540 & 990 \\
\hline Beijing City & 140 & 141 & 282 \\
\hline Total & 3204 & & \\
\hline
\end{tabular}

\section{Conclusions}

National anthropometric surveys are time and money consuming. It's almost solely Chinese government who supported those past surveys, even though body size data is highly evaluated. That's also a reason why there hasn't been new nationwide survey for adult people for so many years. Fortunately, a new national body size survey for adult people is now being initiated by CNIS. More than 20,000 adult people will be measured. Biomechanics and human characteristic parameters are also considered to be covered this time. China Ministry of Science and Technology will support this survey. But CNIS is also looking for some sponsors for this survey. After all, there's only one opportunity for this survey maybe in the coming ten years. It has to be done once for all. 